\title{
Preparedness Plan for the Water Supply Infrastructure during Water Terrorism-A Case Study from Irbid, Jordan
}

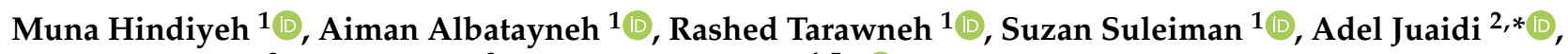 \\ Ramez Abdallah ${ }^{2}$, Salah Jellali ${ }^{3}$ and Mejdi Jeguirim ${ }^{4,5, *(D)}$ \\ 1 School of Natural Resources Engineering and Management, German Jordanian University, P.O. Box 35247, \\ Amman 11180, Jordan; muna.hindiyeh@gju.edu.jo (M.H.); Aiman.Albatayneh@gju.edu.jo (A.A.); \\ R.Altarawneh1@gju.edu.jo (R.T.); Suzan.suleiman@outlook.de (S.S.) \\ 2 Mechanical \& Mechatronics Engineering Department, Faculty of Engineering \& Information Technology, \\ An-Najah National University, P.O. Box 7, Nablus 00970, Palestine; ramezkhaldi@najah.edu \\ 3 Center for Environmental Studies and Research, Sultan Qaboos University, Al-Khoud, Muscat 123, Oman; \\ s.jellali@squ.edu.om \\ 4 CNRS, IS2M UMR 7361, Université de Haute-Alsace, 68100 Mulhouse, France \\ 5 CNRS, IS2M UMR 7361, Université de Strasbourg, 67000 Strasbourg, France \\ * Correspondence: adel@najah.edu (A.J.); mejdi.jeguirim@uha.fr (M.J.)
}

check for updates

Citation: Hindiyeh, M.; Albatayneh, A.; Tarawneh, R.; Suleiman, S.; Juaidi, A.; Abdallah, R.; Jellali, S.; Jeguirim, M. Preparedness Plan for the Water Supply Infrastructure during Water Terrorism-A Case Study from Irbid, Jordan. Water 2021, 13, 2887. https:// doi.org/10.3390/w13202887

Academic Editors: Carmen Teodosiu and Maria Mimikou

Received: 11 September 2021

Accepted: 12 October 2021

Published: 15 October 2021

Publisher's Note: MDPI stays neutral with regard to jurisdictional claims in published maps and institutional affiliations.

Copyright: (c) 2021 by the authors. Licensee MDPI, Basel, Switzerland. This article is an open access article distributed under the terms and conditions of the Creative Commons Attribution (CC BY) license (https:// creativecommons.org/licenses/by/ $4.0 /)$.

\begin{abstract}
Terrorism is a crucial danger to the world, especially the Middle East. As Jordan is amidst countries with armed conflicts, its natural resources (in particularly, water resources) are vulnerable to terrorist attacks. In this paper, possible biological and chemical weapons that can be used as intimidation, along with their threats, vulnerabilities, and inactivation methods, concerning water treatment processes in the municipality of Irbid, are studied. Irbid is the second largest city in terms of population in Jordan, after the capital city of Amman, and it is the nearest governorate to Syria borders that is considered a war zone. After conducting risk assessment that takes into consideration criticality, threats, and vulnerability, it appears that only one of the eight units, which is the Makhraba pumping station, along with the Bushra water tank, were identified as medium risk. The other units have treatment processes and proper precautions that are able to inactivate or prevent any possible contamination. A response plan should be set by developing a telemetry system with specific sensors that can detect any sudden and unacceptable threats to the water quality and that has the ability to shut down the concerned units automatically.
\end{abstract}

Keywords: chemical warfare agents; biological warfare agents; decontamination methods; risk assessment emergency response plan

\section{Introduction}

There is no doubt that water is a necessity for humans and all other forms of life. Water consists of two of the most essential "life" elements-hydrogen and oxygen. Thus, Earth, as we know it, with all of its biological diversity, would have been a completely different planet without water [1]. There is a direct link between human civilization and water. The earliest known human settlement in Jericho was established around 8000-7000 BC; it was located near water bodies and springs, and most nations afterward took the same path to prosperity by keeping the shortest distance possible to water bodies [2]. The significant reliance on water makes it a target for those who want to harm a certain country or a society; in response to that, many scientific efforts have focused on preparedness plans and actions that can mitigate the impacts of terrorist attacks if the occur. According to Steven Curnin and Benjamin Brooks [3], the safety of water systems requires the involvement of experts and specialized associations all together, and it cannot be maintained without their accumulative contributions. On the other hand, the existence of a preparedness plan is not enough to prevent the risk on water systems if the plan is not taught carefully to all 
workers within the water sector, and is not tested and updated frequently. Thus, according to Beck et al. [4], staff training and exercising, as well as disaster simulations, play crucial roles in the reliability and success of the plan. In order to create an accurate preparedness plan for a water system in a specific country, a set of parameters regarding a country must be fully understood and studied in order for the plant to be effective and relevant.

\subsection{Precedence of Water Conflicts}

Water supplies are vulnerable to attacks through intentional contamination or physical attacks on critical facilities, which would deeply affect public confidence and create significant economic disruption. Terrorist attacks on water are not just a 'fear', as there are plenty of examples where water has been utilized as both a tool and a target for attack. It is reported that attacks on water go as far back as $1000 \mathrm{BC}$, when Chinese warriors used arsenic to contaminate the water supplies of their enemies [5]. According to K.H. Butts [6], water has been a source of violent conflict that goes far back to $4500 \mathrm{BC}$ in the battles between the Mesopotamian cities and Umma, and the conflicts are still present to date. In this work, the focus will be on Jordan and its neighboring countries in the Middle East. Appendix A summarizes many of the known water conflicts in the Middle East [7-17].

\subsection{Water Terrorism and Weapons of Mass Destruction}

The United States (US) Justice Department defined terrorism in the following way: "Terrorism is the unlawful use of force or violence, or threatened use of force or violence, against persons and places for the purpose of intimidating and/or coercing a government, its citizens, or any segment thereof for political or social goals." (28 Code of Federal Regulations Section 0.85) [18]. Thus, violence, fear, and intimidation are the three key elements that produce terror in its victims.

FBI Director Robert Mueller [19] made a statement: "Poisoning food and water supplies may be an attractive tactic in the future. A successful attempt might cause thousands of casualties, sow fear among the population, and undermine public confidence in the food and water supply" [19]. Hence, terrorism is not only exclusive to direct armed conflicts or attacks, but can also be directed towards crucial supplies for humans, such as food and water, which can have a much wider impact on larger numbers - up to thousands (rather than small groups) in regard to armed terrorism.

\subsection{Water Chemical and Biological Contamination}

One of the main fears surrounding water systems is that they are varied and spatially spread over large geographic areas. Moreover, water is ingested through drinking and cooking, and inhaled as aerosol in showers. On the other hand, water is used for sanitation and economic purposes (e.g., factories, restaurants). Therefore, water systems are extremely vulnerable to several physical, chemical, and biological threats that might affect system abilities to deliver safe water. Drinking water and wastewater systems contain components that are easy to access and difficult to protect (treatment plants, pumping station units and distribution systems, including standpipes and miles of distribution or collection mains) [20].

According to Gleick [21], chemical and biological contaminants in water could infect individuals via a variety of exposure routes. In order to consider a chemical or a biological weapon as an effective weapon, it must be weaponized and produced in sufficient quantities to have a significant effect; dissolvable and stable in water, infectious, can cause serious illnesses, is hard to detect, and resistant to chlorination, and is inexpensive for the attackers [21].

\subsubsection{Chemical Contamination of Water}

Chemical contamination of water is a substantial threat to human health and safety, and is expected to have impacts that are more significant in the upcoming decades. According to Amrose et al. [22], the impacts of chemical contamination on humans may increase, 
mainly due to increasing industrialization and climate change. The most common chemical contaminants that affect the quality of water are the following:

- Cyanide: cyanide is an environmental contaminant that is produced by industrial processes that pump their waste into drinking water. Cyanide compounds are available on both worldwide open and black markets and are mainly used in the metal-processing industry. Mining operations that use cyanide compounds in the extraction of metals are one of the biggest sources for cyanide that can be found in water [23]. According to the World Health Organization (WHO) [24], the maximum recommended concentration level (MRCL) for cyanide in water is $70 \mu \mathrm{g} / \mathrm{L}$, while the Environmental Protection Agency (EPA) [25] had set this MRCL at $200 \mu \mathrm{g} / \mathrm{L}$.

- Pesticides: pesticides are widely used in agriculture, in homes, gardens, or farms. Pesticides are not considered as a source of acute health effects, since they are usually found in very low concentrations in water supplies. In the case of their presence, there might be a chance of some moderate health risks, such as chemical burns, nausea, or convulsions. However, even in trace levels, pesticides can induce serious chronic health problems [26].

- Arsenic: arsenic exists naturally in soils and minerals. It could be transferred to the air through wind-blown dust and to water resources via runoff and leaching. Ingesting high doses of arsenic can result in serious health conditions that can cause death. Exposure to lower doses can cause minor to moderate health issues, such as vomiting, nausea, a decrease in the production of red and white blood cells, and abnormal heart rhythms [27]. The WHO has set the MRCL for arsenic in water as $10 \mu \mathrm{g} / \mathrm{L}$, which is the same value set by the EPA [24,25].

- Sulfur mustard agents: sulfur mustard is a well-known chemical warfare agent. The direct contact with sulfur mustard agents commonly results in blistering of mucous membranes. Hence, they are called blistering agents or vesicants. Even though sulfur mustard may smell like onion or garlic, it sometimes has no odor, which makes the detection harder and more challenging. In terms of physical phase, sulfur mustard can be found in three phases - vapor, oily-textured liquid, or a solid. The variability extends even more since sulfur mustard can be in different colors when present in water; it can be clear to yellow or brown when it is in liquid or solid form. The complexity of sulfur mustard is mainly due to the fact that it is not a naturally produced substance in the environment, and it was introduced in World War I as a chemical warfare agent [28]. According to Dacre and Burrows [29], the MRCL for sulfur mustard agents in drinking water is $47 \mu \mathrm{g} / \mathrm{L}$ when consuming 15 liters per day (L/day) and $140 \mu \mathrm{g} / \mathrm{L}$ if consuming $5 \mathrm{~L} /$ day.

- Organophosphorus nerve agents: organophosphorus nerve agents have been widely weaponized as chemical warfare agents since the first half of the 20th century, according to Dunn and Sidell [30] and Somani et al. [31]. Organophosphorus nerve compounds are the most toxic of the known chemical agents, which include Sarin (GB), Tabun (GA), Soman (Agent GD), and Agent VX (Table 1).

Table 1. Main physical properties of organophosphorus nerve agents [32].

\begin{tabular}{|c|c|c|c|c|}
\hline $\begin{array}{ll} & \text { Nerve Agent } \\
\text { Property } & \end{array}$ & Sarin (GB) & Soman (GD) & Tabun (GA) & VX \\
\hline Color & Colorless & Colorless & Colorless & Amber \\
\hline Odor & Odorless & Camphor & Fruity & Odorless \\
\hline Taste & Tasteless & Tasteless & Tasteless & Tasteless \\
\hline Solubility in water & Miscible & $2.1 \mathrm{~g} / 100 \mathrm{~g}$ at $\left(20^{\circ} \mathrm{C}\right)$ & $9.8 \mathrm{~g} / 100 \mathrm{~g}$ at $\left(25^{\circ} \mathrm{C}\right)$ & $\begin{array}{c}3 \mathrm{~g} / 100 \mathrm{~g}(\text { miscible } \\
\left.\text { below } 9.4^{\circ} \mathrm{C}\right)\end{array}$ \\
\hline Liquid density & $1.10 \mathrm{~g} / \mathrm{mL}$ at $\left(20^{\circ} \mathrm{C}\right)$ & $1.02 \mathrm{~g} / \mathrm{mL}$ at $\left(25^{\circ} \mathrm{C}\right)$ & $1.08 \mathrm{~g} / \mathrm{mL}$ at $\left(25^{\circ} \mathrm{C}\right)$ & $1.008 \mathrm{~g} / \mathrm{mL}$ at $\left(20^{\circ} \mathrm{C}\right)$ \\
\hline
\end{tabular}




\subsubsection{Biological Contamination of Water}

According to Valcik [33], biological threats are classified into two main categoriespathogens and toxins. Pathogens are living organisms, such as viruses, bacteria, and protozoa. On the contrary, toxins are chemicals that are made from biological processes. Table 2 includes some examples for each type [21]:

Table 2. Examples of biological contaminants of water, their sources, and accessibility [21].

\begin{tabular}{|c|c|c|c|c|}
\hline \multicolumn{2}{|c|}{ Biological Contaminants } & \multirow{2}{*}{$\begin{array}{c}\text { Examples } \\
\text { Brucella spp., Bacillus anthracis, } \\
\text { Burkholderia spp., Campylobacter spp., } \\
\text { Francisella tularensis, Clostridium } \\
\text { perfringens, Vibrio cholera, E. coli O157:H7, } \\
\text { Salmonella typhi, Shigella spp. }\end{array}$} & \multirow{2}{*}{$\begin{array}{l}\text { Limited Access } \\
\text { Yes, for specified } \\
\text { agents }\end{array}$} & Sources \\
\hline \multirow{3}{*}{ Pathogens } & Bacteria & & & \multirow{3}{*}{$\begin{array}{l}\text { Naturally occurring, } \\
\text { microbiological } \\
\text { laboratories }\end{array}$} \\
\hline & Viruses & $\begin{array}{l}\text { Caliciviruses, Enteroviruses, Hepatitis } \\
\text { A/E, Variola. }\end{array}$ & $\begin{array}{l}\text { Yes, for specified } \\
\text { agents }\end{array}$ & \\
\hline & Parasites & $\begin{array}{l}\text { Cryptosporidium parvum, Entamoeba } \\
\text { histolytica, Toxoplasma gondii. }\end{array}$ & No & \\
\hline Bio-toxins & $\begin{array}{l}\text { Biologically } \\
\text { produced } \\
\text { toxins }\end{array}$ & $\begin{array}{l}\text { Bio-toxins from plants, fungi, protists, } \\
\text { bacteria, defensive poisons in some } \\
\text { marine or terrestrial animals, such as T-2 } \\
\text { mycotoxins, ricin, microcystins, saxitoxin, } \\
\text { botulinum toxins. }\end{array}$ & Yes & $\begin{array}{l}\text { Laboratory, supplier, } \\
\text { pharmacy, natural } \\
\text { source, state-sponsored } \\
\text { military programs }\end{array}$ \\
\hline
\end{tabular}

The Centers for Disease Control and Prevention (CDC) have categorized biological warfare agents into three categories [34]:

Category A: The highest priority agents; they include organisms that pose a serious risk to national security as they can be easily transmitted from humans and are easily disseminated. Category A agents commonly result in high death rates and have the potential for major public health impacts. They might also cause social disruption and panic, and they require extensive preparedness and action for public health. The common diseases/agents linked to this category are:

Tularemia (Francisella tularensis);

Plague (Yersinia pestis);

Anthrax (Bacillus anthracis);

Smallpox (Variola major);

Botulism (Clostridium botulinum toxin);

Viral hemorrhagic fevers (Filoviruses and Arenaviruses).

Category B: The second highest priority agents. They are those agents that are moderately easy to disseminate. They result in low death rates but moderate morbidity rates. Some related disease/agent are:

Typhus fever (Rickettsia prowazekii);

$\mathrm{Q}$ fever (Coxiella burnetii);

Glanders (Burkholderia mallei);

Brucellosis (Brucella spp.);

Epsilon toxin (Clostridium perfringens);

Viral encephalitis (Alphaviruses);

Melioidosis (Burkholderia pseudomallei);

Psittacosis (Chlamydia psittaci);

Ricin toxin (Ricinus communis);

Staphylococcal enterotoxin B (Staphylococcus spp.);

Water safety threats (Vibrio cholerae, Cryptosporidium paroum);

Food safety threats (Salmonella spp., E. coli O157:H7, Shigella). 
Category C: The third highest priority agents. They include emerging pathogens that can be engineered for dissemination in the future. These pathogens are highly available, easy to produce and disseminate, and can have high potential for elevating morbidity and mortality rates. The common agents of this category are Nipah virus and Hantavirus.

In conclusion, the Middle East (in general) and Jordan (in particular) can be subjected to major threats through the contamination of their water bodies and resources, by either terrorist individuals or groups. Thus, in this study, a risk analysis is implemented to assess the criticality of the water safety against chemical and biological terrorism in Jordan, specifically in the city of Irbid, which is located in the north of the country, which makes it more vulnerable than any other Jordanian city since it has borders with Syria. Thereafter, a risk mitigation strategy is proposed for implementation in order to be prepared for any unfortunate events that can affect the water safety in Irbid.

\section{Materials and Methods}

Water sources in Jordan are composed of 15 surface water bodies and 12 groundwater basins. The number of active wells in Jordan exceeds 3000 wells $[35,36]$. Jordan's total annual water demand is estimated to be 1412 million cubic meters (MCM). Unfortunately, the per capita water supply in Jordan, for all purposes, is less than $15 \%$ in comparison to worldwide standards. Jordan is one of the most water scarce countries in the world; thus, safety and sanitation of water is a crucial aspect that must be dealt with in the most exhaustive way. The amount of annual treated wastewater in Jordan is around $140 \mathrm{MCM}$. About $92 \%$ of this amount is directly or indirectly reused [37]. Water supply in Jordan occurs from surface and groundwater resources through various pumping stations located all over the country (Table 3) [38].

Table 3. Water pumping stations in Jordan.

\begin{tabular}{cccr}
\hline Governorate & Pumping Stations No. & Reservoir No. & Reservoirs Capacity (10 $^{\mathbf{3}} \mathbf{~}^{\mathbf{3}}$ ) \\
\hline Amman & 51 & 83 & 700 \\
\hline Irbid & 73 & 52 & 127 \\
\hline Zarqa & 44 & 22 & 60 \\
\hline Aqaba & 4 & 24 & 46.4 \\
\hline Balqa & 73 & 33 & 57.2 \\
\hline Madaba & 10 & 5 & 57.2 \\
\hline Karak & 16 & 17 & 29.7 \\
\hline Ma'an & 32 & 18 & 27.3 \\
\hline Mafraq & 58 & 44 & 15.5 \\
\hline Ajloun & 12 & 22 & 15 \\
\hline Tafielah & 18 & 7 & 13.9 \\
\hline Jerash & 12 & 14 & 9.7 \\
\hline
\end{tabular}

\subsection{Case Study: Irbid City}

Irbid is a Jordanian city that is located in the north of the country. It has the second largest population in Jordan after the capital city Amman, and it has the highest population density in Jordan. Irbid is the nearest governorate to Syria borders, which is considered a war zone. Groundwater wells from Wadi Al Arab well fields are the current major sources of potable water for the city of Irbid. As mentioned earlier, Irbid has 73 water pumping stations and 52 water reservoirs, but in this study, the focus is only on 6 pumping stations and 3 water reservoirs, including Wadi Al-Arab wellfield, and 1 water treatment plant $[39,40]$. Figure 1 shows the location of each water asset and Appendix B presents the observations that were obtained upon site visits to each asset. 


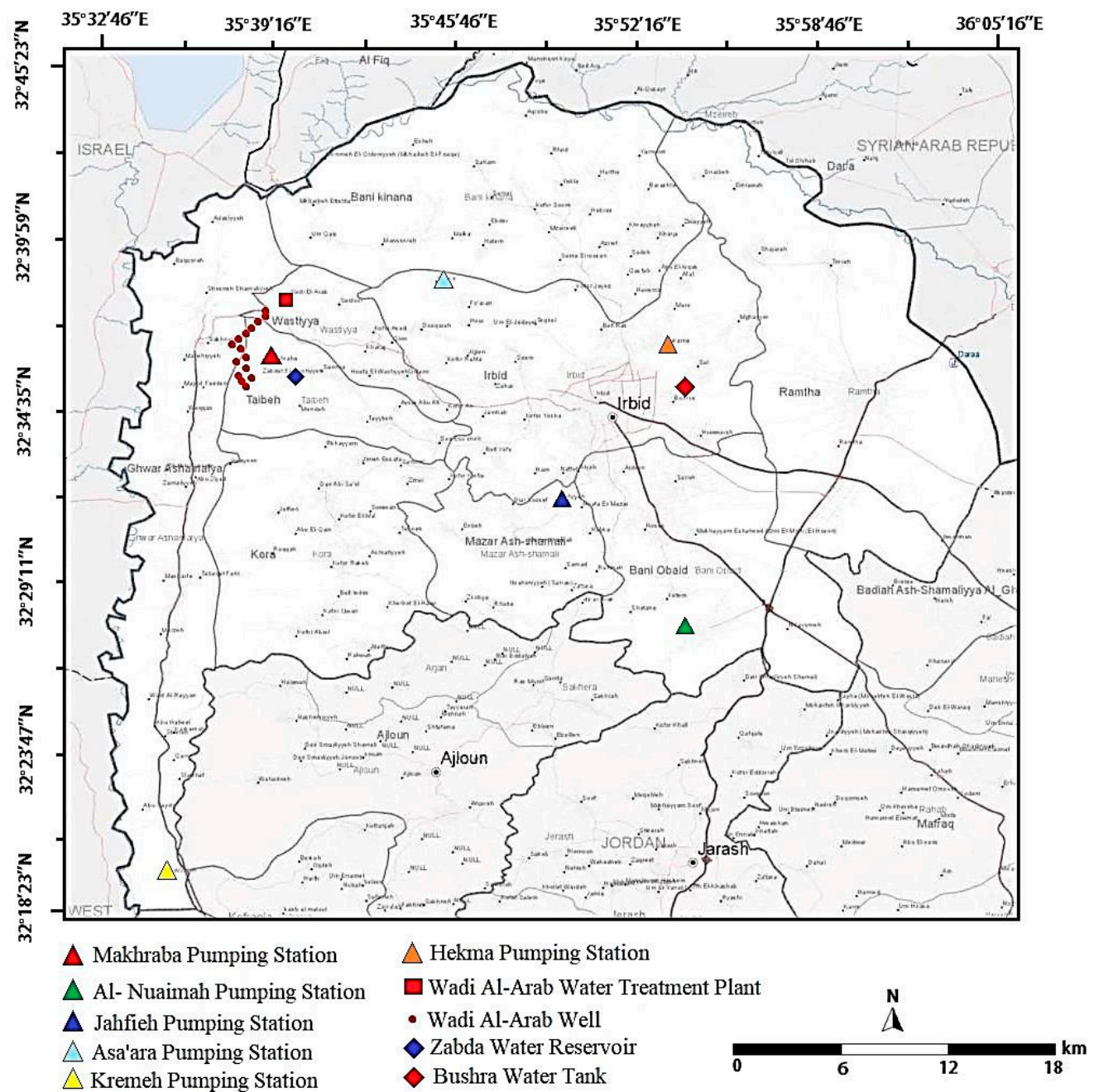

Figure 1. Map of studied water assets in Irbid.

In order to be prepared for chemical and biological agents attacking the water supply, an initial assessment of water systems in the area should be conducted, followed by quantitative and qualitative risk and vulnerability assessments, operational formulations, and models for homeland critical infrastructure protection. First, the different components of water systems in Irbid, Jordan, should be identified and thoroughly studied. Afterwards, a risk assessment should be conducted to identify components subjected to high risks. Finally, an early warning program, and a response plan are to be set, in which possible risks can be avoided and, in case of threat detection, proper measures should be taken.

\subsection{Risk Analysis and Management for Critical Assets Protection Plus}

The risk analysis and management for critical asset protection (RAMCAP) is a quantitative method by which estimated values can be made regarding several aspects concerning the national infrastructure; these aspects are risk, resilience, vulnerability, potential threat, and consequence. Five threat levels are shown in Table 4 and they vary from level 1 (negligible) to level 5 (extreme). The RAMCAP Plus model defines risk as the product of potential threat, vulnerability, and consequence in the same way that the department of homeland security (DHS) defines risk [41]. The basic DHS risk (R) assessment equation is as follows [42]:

$$
\mathrm{R}=\mathrm{T} \times \mathrm{V} \times \mathrm{C}
$$

T: potential threat;

V: vulnerability; 
C: consequences.

Table 4. Threat assessment and description criteria.

\begin{tabular}{cccccc}
\hline \multirow{2}{*}{$\begin{array}{c}\text { Threat } \\
\text { Assessment }\end{array}$} & Existence & Targeting & Capability & History & Intentions \\
\cline { 2 - 6 } Extreme (5) & Yes & Yes & Yes & No & No \\
\hline High (4) & Yes & No & Yes & Yes & Yes \\
\hline Medium (3) & Yes & No & Yes & Yes & No \\
\hline Low (2) & Yes & No & Yes & No & No \\
\hline Negligible (1) & No & No & No & No & No \\
\hline
\end{tabular}

\subsubsection{Threat Characterization for Irbid Water Infrastructure}

The main threats to the Irbid water infrastructure are:

- Introduction of poison to water tanks located in major communities.

- Attack of the security personnel, bombing of freshwater and wastewater treatment facilities. Destruction of structures within the facilities. Mainly destroy major water and wastewater pipelines.

- Intentional pollution with heavy metals and industrial chemicals, such as cyanide, protozoa, bacteria, viruses, and toxins. Cow farms and agricultural activity waste may reach the wellheads during rainfall, causing fecal contamination and turbidity, bad odor, and pollution with nitrogen compounds.

2.2.2. Scenarios for the Routes of the Chemical and Biological Agents to Contaminate the Water Supply in Irbid

The following attack scenarios on the Irbid water infrastructure, via chemical and biological agents, are considered:

- Introduction of biological/chemical agents to source water: within Irbid, drinking water is mainly collected from wells, such as Wadi-AL-Arab wells, Tabaqet Fahel wells, and many other wells from the surrounding areas. Since the collected water is sent to a treatment facility, biological and chemical agents can be introduced at the source, injected in wells or springs, or during transport to the treatment facility.

- Introduction of agent to storage tanks/facility: water stored in tanks before distribution can be intentionally contaminated through access to storage tanks. A terrorist could possibly contaminate water in storage tanks, since it would no longer undergo treatment; hence, the effect of contaminated water is greater. In this case, free available chlorine (FAC) could act as a disinfectant for the decontamination of the biological agents. The water quality parameters should therefore be continuously monitored within each tank, and the use of an early warning system is advisable.

- Introduction of agent to distribution network: the most likely 'terrorist contamination' source would be via the distribution network, served by the pipe or the affected distribution network, due to use and ingestion of the contaminated water. This would result in an epidemic, infecting a portion of the population. Although residual chlorine is present within a distribution network, it may not be sufficient to disinfect or inactivate the added biological contaminants.

\subsection{Consequences Assessment}

"Consequence" is defined as the magnitude and type of damage resulting from successful terrorist attacks. To define a measure of consequence, specificity is again required.

Measure (consequence): the expected magnitude of damage (e.g., deaths, injuries, or property damage), given a specific attack type, at a specific time, results in damage to a specific target. Table 5 present the different levels of consequences and their descriptions. 
They vary from level 1 (negligible) corresponding to insignificant damage of the equipment and no loss of life, to level 5 (extreme), which would give tactical advantage to terrorists to perform further plans.

Table 5. Consequences assessment and description criteria.

\begin{tabular}{cc}
\hline Consequences & Description \\
\hline Extreme (5) & Loss of life or permanent damage to a facility resulting in costly \\
High (4) & repairs. \\
Medium (3) & Serious and costly damage to a facility. \\
Low (2) & Minor disruption to operations in the facility. \\
Negligible (1) & Insignificant damage to facilities and minimal budget loss. \\
\hline
\end{tabular}

Consequence $=\mathrm{E}$ (damage $\mid$ attack occurs and results in damage).

\subsection{Vulnerability Analysis}

According to the DHS [41], the vulnerability analysis estimates the probability of a successful terrorist attack. Vulnerability is also defined as the weaknesses in the design or operation of an infrastructure, which can be used by a terrorist to generate a disaster. The vulnerability of a facility depends on several factors, including ease of access, security measures, and response to breech (Table 6).

Table 6. Vulnerability assessment and description criteria.

\begin{tabular}{|c|c|}
\hline Vulnerability & Description \\
\hline High (5) & 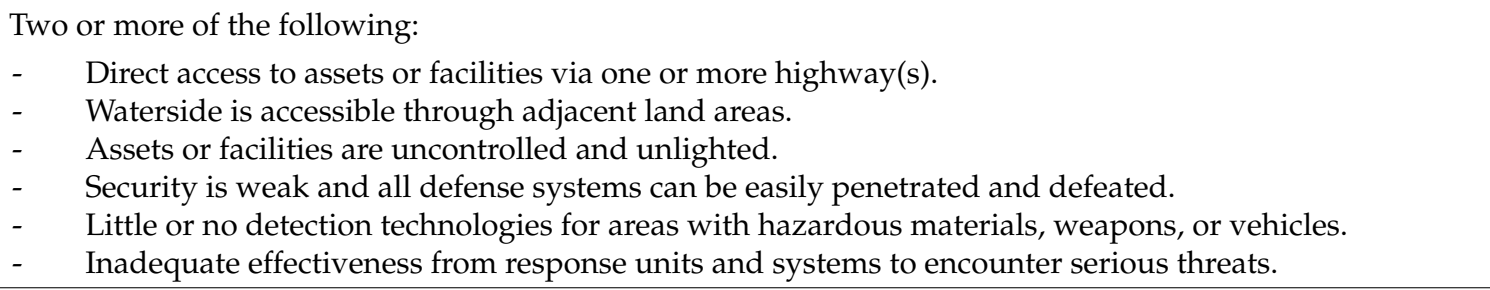 \\
\hline Moderate (3) & $\begin{array}{l}\text { Two or more of the following: } \\
\text { - } \quad \text { Direct access to assets or facilities via one or more highway(s), but road system is restricted. } \\
\text { - } \quad \text { Waterside is accessible through adjacent land areas, but mitigating obstacles may be present. } \\
\text { - } \quad \text { Assets or facilities are uncontrolled and unlighted. } \\
\text { - } \quad \text { Security is weak and all defense systems can be easily penetrated and defeated. } \\
\text { - } \quad \text { Moderate or little detection technologies for areas with hazardous materials, weapons, or vehicles. } \\
\text { - } \quad \text { Moderate effectiveness from response units and systems to encounter serious threats. }\end{array}$ \\
\hline Low (1) & $\begin{array}{l}\text { Two or more of the following: } \\
\text { - } \quad \text { No direct access to assets or facilities via one or more highway(s). } \\
\text { - } \quad \text { Adequate access control, including cameras, sensors, patrols, and reporting systems to prohibit the } \\
\text { access of any unauthorized individual or group. } \\
\text { - } \quad \text { Safeguards and detection technologies for areas that contain hazardous materials, weapons, or vehicles. } \\
\text { - Well-trained and equipped response forces that can operate spontaneously in the case of a breach. }\end{array}$ \\
\hline
\end{tabular}

\section{Results and Discussion}

The methodology mentioned previously was adopted for the assessment of risk regarding the chosen drinking water treatment units in Irbid. Drinking water sources and pumping units were described and studied earlier, explaining the methods used for disinfection and treatment. Usually most drinking water units are sufficiently secured; they lay within concrete walls, security guards are available $24 \mathrm{~h}$ in shifts, and authorized persons are the only people allowed in. This makes it difficult for break-ins and security breaches to occur. Additionally, the units are provided with surveillance systems, including 
cameras that enable the continuous monitoring of drinking water systems. The most important observations were that Wadi-Al-Arab and Bushra wells do not have sophisticated fencing and have easy access. Hence, they are not well protected. Identifying the attacker as a terrorist group, the existence, and capability of the terrorist group is highly relevant, while no history of similar terrorist attacks on drinking water facilities is present.

According to the scale mentioned above, and for all the drinking water facilities, threat is assessed as low, with 2 points on the 5-point scale (see Table 4). Most of the drinking water units in Irbid depend on chlorination as a disinfecting agent, while one of the units is only used for pumping purposes, this is the case in the Makhraba pumping station, which was given 5 points on the vulnerability, since any chemical/biological agent introduced can only be disinfected through the free available chlorine (FAC) available within the already treated water. FAC is also known as chlorine residual; it is the portion of chlorine that does not go through any reactions, and could still be used for the disinfection of water. Other units in which only chlorination takes place were given 3 points on the vulnerability scale, because the introduction of the agent can be decontaminated only by chlorination means. The least vulnerable units are those adopting more than one treatment process, such as Asa'ara and Hekmah units, which use ventilation, sand filters, and chlorination, and the Kremah unit, which utilizes sand filters, membrane filters, and membrane cartridges that produce water of high quality. Table 7 presents the descriptions of the treatment processes used in the chosen drinking water units, as well as the assessed consequences, threats, vulnerabilities, and the risks.

Table 7. Drinking water units' risk assessment.

\begin{tabular}{|c|c|c|c|c|c|}
\hline Drinking Water Units & Treatment Process & Consequences & Threat & Vulnerability & Risk \\
\hline Wadi Al-Arab & $\begin{array}{l}\text { Only Chlorination and } \mathrm{Al}_{2}\left(\mathrm{SO}_{4}\right)_{3} \\
\left(\mathrm{KMnO}_{4}\right) \text {, Polymers if Turbidity } \\
\text { exceeds } 60 \mathrm{NTU}\end{array}$ & 3 & 2 & 3 & 18 \\
\hline Carrier line & Chlorination at line & 3 & 2 & 3 & 18 \\
\hline Al-Nuiamah & Chlorination & 3 & 2 & 3 & 18 \\
\hline Jahfieh & Chlorination & 3 & 2 & 1 & 6 \\
\hline Asa'ara & $\begin{array}{l}\text { Chlorination, ventilation and sand } \\
\text { filters }\end{array}$ & 3 & 2 & 1 & 6 \\
\hline Makhraba & Pumping station only & 3 & 2 & 5 & 30 \\
\hline Bushra & Water storage tank only & 3 & 2 & 5 & 30 \\
\hline Hekmah & $\begin{array}{c}\text { Chlorination, ventilation and sand } \\
\text { filters }\end{array}$ & 3 & 2 & 1 & 6 \\
\hline Kremeh & $\begin{array}{l}\text { Chlorination, sand filters, membrane } \\
\text { filter and cartridge filter }\end{array}$ & 3 & 2 & 1 & 6 \\
\hline
\end{tabular}

Since the used method does not provide a full description for the numerical scale for the overall risk assessment, a proposed descriptive scale will be used to define high, moderate, and low risk. Table 8 shows how low, moderate, and high risk has been identified.

- If the calculated score lies between 1 and 27, the risk is considered low or minimal; an attack to the facility will not severely affect its processes, equipment, or the public consumers.

- If the assessed score exists in the range 27-80, the risk is considered medium, with some disruption to the facility activities; harm caused to consumers is low.

- Any score above 80 is considered of high risk and the facility is easily vulnerable; disruption of processes occurs, resulting in severe effects on consumers, with diseases spreading that might lead to death. 
Table 8. Proposed risk assessment scale.

\begin{tabular}{ccccc}
\hline Description & Consequences & Threat & Vulnerability & Risk \\
\hline Extreme & 5 & 5 & 5 & 125 \\
High & 4 & 4 & 3 & 27 \\
Medium & 3 & 3 & 3 & 12 \\
Low & 2 & 2 & 1 & 1 \\
Negligible & 1 & 1 & &
\end{tabular}

The results of the proposed assessment show that of the eight drinking water treatment units, Makhraba pumping, and Bushra Tank station are the ones with 30 points on the risk scale, which indicates that their risks are slightly above moderate; this is mainly due to their high vulnerability levels. While all other stations are of low risk, since they are all well secured and monitored, and the treatment processes adopted eliminate the possibility of contamination if the contaminant is added within the facility before treatment processes start (or at the source). Since Makhraba is a pumping station only, and is exposed to moderate risk, stricter security measures should be applied, and an increase in chlorine levels within the water is recommended

\section{Preparedness Plan and Recommendations}

The following plan and recommendations are viable to all stations and water assets, but are more crucial and important for implementation in the Makhraba pumping station and Bushra water tank.

\subsection{Mitigation of Risk through Staff Awareness}

Mitigation steps, policies, and training programs can be set and implemented to reduce the risks that target drinking water utilities in general, and the Makhraba pumping station and Bushra water tank specifically. Moreover, the staff of all water facilities must be aware of their responsibilities and the criticality of their positions. For instance, the staff must be aware about the sensitivity of the information they have. Hence, the following recommendation must be followed.

Avoid listing sensitive information about the operation of a water system that might be useful for terrorists, such as specific locations of the system components. Additionally, no details of utility security and water system information should be shared with the public or media. Sensitive information should mainly include [43]:

- Confidential information - "very limited access": information that could be exploited by terrorists in planning attacks on utility assets.

- $\quad$ Restricted information-"need to know": data, information that should not be provided to public, but may be disclosed to utility representatives.

- Public information: data that could be provided to the public with few or no restrictions, including water quality reports and brochures.

- Moreover, the following precautions should be taken into account:

- Identification of employees and visitors.

- Badges can range from simple photo IDs to electronic identification devices that electronically control access, to tracking systems that monitor an individual's movement within a facility.

- Key security.

- A formal key-control program should be maintained and documented listing who has been issued specific keys, for what purposes, and by whom.

- Spare copies should be maintained in a secure manner. 
4.2. Mitigation of Risk through Physical Protection Systems the Following Physical Protection Measures Should Be Applied

- Access Control: the access control can be used to regulate entry into a particular building or specific rooms and areas within the building. One of the most basic access control devices are doors and locks. Door locks can be either mechanical or electronic and it is advised that both mechanical and electrical locks be used to limit the access as much as possible. Mechanical locks are ineffective if an adequate key control system is not in place. Keys have to only be distributed to people who have a legitimate need for access to a particular building or room. Certain keys should be numbered and tracked through a computerized log system and each key should be stamped with the statement "Do Not Copy". Electronic locks can be available as card-reader locks, electric cards, biometric locks activated by the correct fingerprint, eye pattern, signature recognition, or PIN number.

- Lighting: it is one of the least expensive security measures to install. It makes the area more visible, and bans and prohibits an adversary who seeks to remain undetected. It also makes it easier to detect any illegal intrusion. Burning lights can also give a 'hint' and draw more attention to the fact that an area is being intruded and occupied. Motion detectors is another option, where extra bright lights are activated if any movement passes through the sensor.

- Fences, walls, and gates: they are considered some of the most important security components for freshwater and wastewater treatment plants, pumping stations, and reservoirs. Wire and iron fences consist of strong steel wires that are resistant to cutting and breaking. Walls are also used to provide boundary protection. Stone or brick walls can visually dim/obscure the protected site from the outside view. They are more difficult to penetrate than fences. Gates provide access to walls or fences and they can be enhanced by using locking-unlocking devices. Their styles range from simple swinging gates to those that slide open in response to a sensor when authorized vehicles approach. To improve security, a perimeter fence or wall has to be located at an adequate and convenient standoff- "the distance between the protected site and the outside perimeter" in order to have a clear zone. Fence associated sensors are external sensors are installed or within the fences. They are activated when fences are climbed, or cut.

- Exterior intrusion detection sensors: intruders crossing a boundary and entering the protected zone can be discovered by sensors placed in a clear zone, e.g., along the fence lines. These sensors should have enough capability to withstand atmospheric conditions, such as (heat, cold, snow, rain, wind), but also be sensitive enough to detect intrusion during harsh environmental conditions. There are two categories of exterior intrusion sensors: passive and active. Passive sensors emit no energy. Rather, they rely on the intruder to produce energy, such as body heat, or impact the fence or the ground. Fence vibration detector, passive infrared sensors, and video motion detectors are examples of passive sensors. Active sensors transmit and receive energy, such as microwave or active infrared.

- Interior intrusion detection sensors: in case any intrusion takes place without being detected by the exterior intrusion detection sensors along fence lines-the interiors of water facilities must be equipped with motion detectors, heat detectors, and cameras that are all connected to monitors in a control room, in which a well-trained guard must be placed to ensure that the facility is not being intruded.

- Reservoir cover: the open finish water reservoirs must be covered to prevent contaminants from entering the finished water, or it has to be treated again before being distributed. This provides a kind of protection against any intentional or accidental contaminants that may have entered during storage. The cover should be tough enough to resist any intrusion. Thin plastic materials, such as polypropylene, which can be easily breached, have to be avoided. 


\subsection{Use of Water Contaminant Information Tool (WCIT)}

WCIT is a secure and web-accessible site that provides information on various types of contaminants that could pose a threat to people or the infrastructure if they are introduced to a drinking water system. Types of information that are provided by WCIT include contaminant names, availability, fate, and their characteristics in water, health effects, and some basic guidance on decontamination. As a research tool, WCIT helps identify knowledge gaps for priority contaminants that, in turn, will guide future research efforts [44].

\subsection{Implementation of Contamination Warning System (CWS)}

This system was originally referred to as the Early Warning System (EWS) because the goal was to detect a contamination incident early enough to warn the population at risk and to initiate response actions possibly after initial exposure to minimize the economic and public health impacts of an event. The main component of a CWS is a continuous, online monitoring with analytical equipment that can be implemented at different sites in the distribution networks or water treatment plant facilities. Sensors can be utilized in drinking water systems to monitor the raw water coming into the treatment plant and the finished water leaving the plant. The CWS can provide benefits because it might recognize and identify accidental as well as intentional contamination. It can permit the measure of basic parameters, such as $\mathrm{pH}$, electrical conductivity, temperature, chlorine, as well as other specific contaminants through multi-array sensors (Table 9). It is advised to temporarily shut down the water system connected to a specific contaminated water asset as soon as any contamination is detected in order to give sufficient time for authorities to take action and to minimize exposure by end users as much as possible.

Table 9. Suggested sensors for contamination detection and management.

\begin{tabular}{cc}
\hline $\begin{array}{c}\text { Chemical sensor (detect presence of chemical } \\
\text { agent and sensing releases of highly toxic } \\
\text { compound }\end{array}$ & Micro-electro mechanical systems (MEMS) \\
\hline $\begin{array}{c}\text { Temperature sensor (detect temperature } \\
\text { variations) }\end{array}$ & IR sensor, thermistor \\
\hline Explosives presence detection & Chemical vapor detectors \\
\hline Fingerprint for individuals identification & Thermal, visual, pressure sensors \\
\hline
\end{tabular}

\subsection{Communication with Public}

There should be direct and clear communication between public health departments and drinking water departments in order to clear doubts regarding disease spread due to possible water contamination. In case an epidemic due to water contamination occurs, water authorities should issue a public notice regarding water use, and inform agencies about water situations, stating water status, areas affected, and water contamination. Communication with the public is a very important aspect in any contamination scenario; the public should always be updated with the status regarding contamination issues, and the progress of decontamination, for them not to lose credibility and trust in the government and in water agencies. Officials should be the only people reporting to public media, including trusted newspapers, televisions, and magazines, so that no rumors are spread that would result in raising panic within the community.

\subsection{Sampling and Water Decontamination Methods}

Boiling water is a simple solution for the inactivation of contaminants in drinking water, which can be implemented by the majority of the consumers easily and without a need for special equipment or disinfectants for it to be an effective method. It is also efficient, i.e., whether water is clear, cloudy, relatively pure, or highly contaminated. Boiling water, whether through conventional methods or with electric, has the same effect. The WHO [24] recommends bringing water to a rolling boil, with large bubbles continuously 
coming to the surface, and maintaining this condition for at least $1 \mathrm{~min}$. People living in areas with high elevations should boil water for 1 extra minute for every $1000 \mathrm{~m}$ above sea level. If water is not clear, filtration of water using a clean cloth is recommended before boiling. Another method for the disinfection of water, in the case of not being able to boil the water, is using unscented bleach. A small amount of bleach is enough for the disinfection of water. The following sub-sections contain several decontamination methods for biological and chemical contaminants.

\subsubsection{Cyanide Decontamination}

There are many methods for the decontamination of cyanide from water. For instance, in a study carried out by Huff and Bigger [45], they found that activated carbon mixed with copper could be used to adsorb cyanide from water in an adsorption rate of around $25 \mathrm{mg} / \mathrm{g}$. Following the same approach of decontamination of cyanide via activated carbon, Adams [46] found that the most superior carbon-based decontamination is the wood carbon-based treatment. At a $\mathrm{pH}$ of 7 , around $90 \%$ cyanide removal had been obtained within 8 hours with the addition of 1.5 grams of carbon to a solution of 1 liter containing 256 milligrams of cyanide. Another proposed way for cyanide decontamination is chlorination. However, according to the WHO [47], chlorination is unlikely to be a practical way for cyanide decontamination since it requires a two-stage treatment process that does not ensure the complete oxidation of cyanide to form nitrogen, except in some specific cases.

\subsubsection{Pesticides Decontamination}

As mentioned earlier, pesticides are not as lethal or common as other chemical contaminants. Therefore, minimal research focus has been placed on decontaminating water from pesticides. There was a study conducted by Weltmer et al. [48], regarding the decontamination methods that were implemented after an intentional contamination of water in Pittsburgh, Pennsylvania, in 1980, where an unknown perpetrator contaminated water via large amounts of chlordane. The contaminated water was constrained within the system and a flushing process was implemented for decontamination. Unfortunately, even after the flushing process, the study pointed out that Chlordane was still detectable within the water system up to nine months after the decontamination flushing. Other relatively costly methods, such as advanced oxidation processes that permit complete mineralization of organic compounds, could be applied for pesticide removal from the contaminated water.

\subsubsection{Arsenic Decontamination}

Arsenic is commonly found in two oxidized forms-arsenite and arsenate, and numerous decontaminations were found effective for the removal of both forms, such as coagulation, chemical oxidation, advanced oxidation processes, adsorption, ion exchange, and membrane filtration [49]. For instance, in several studies, it was reported that membrane filtration processes, including nanofiltration (NF) and reverse osmosis (RO), could achieve removal efficiencies ranging between $85 \%$ and $99 \%$ in the case of arsenate, and $61 \%$ to $87 \%$ for the arsenite. Moreover, the electrocoagulation process was pointed out as one of the most promising and effective methods. It possesses a large number of advantages over other methods, such as less capital costs, less, less required area, and less technical skills for technical operation [50].

\subsubsection{Sulfur Mustard Agents Detoxification}

Many technologies for the detoxification of sulfur mustard gas were proposed by scientists. For example, catalytic hydrolysis can be an effective route for the removal of sulfur mustard gas from water, but the process produces harmful by-products, such as $\mathrm{HCl}$, and some by-products may coat the particles of sulfur mustard gas, resulting in a delay in the detoxification process [51]. Another promising method is the oxidation of sulfur mustard gas into sulfoxide. However, a selective oxidation must be done in order to avoid 
the formation of harmful by-products, such as in the case of over-oxidation, where there can be a formation of bis(2-chloroethyl) sulfoxide, which has very similar health issues to the ones linked with sulfur mustard gas [52]. Finally, according to Jabbour et al. [53], hydrophobic metal-organic frameworks (MOFs) with the use of amphiphilic catalysts are preferred for the removal of sulfur mustard gas and its stimulants from water.

\subsubsection{Organophosphorus Nerve Agents Detoxification}

According to Talmage et al. [54], the detoxification of nerve agents is usually done by hydrolysis or oxidation. However, it is more preferable to use oxidation since the hydrolysis of nerve agents can result in the formation of more toxic by-products [54]. Yet, research is still oriented more frequently onto hydrolysis processes. One of the most recent studies regarding the detoxification of nerve gases was done by Moon et al. [55], in which they proposed the use of MOF catalysts containing Zr6 clusters. The results were satisfactory, as Zr-MOFs showed a high catalytic activity for the hydrolysis of simulants and nerve agents in buffer solutions.

\subsubsection{Decontamination of Water from Several Pollutants at Once}

The detection and decontamination of water in the case of multiple pollutants is still a worldwide concern to date. M. Bartolomeu et al. [56] proposed a strategic procedure to deal with the contamination of water by several pollutants, in which they suggest a full plan of various chemical, physical, and biological stages. The first step is the primary treatment stage, which mainly focuses on the physical treatment of water via physical barriers (i.e., filters), gravity, and density difference for the removal of large sediments, as well as oils, grease, and scum. Afterwards, the secondary treatment stage takes place in biological reactors in which water is subjected to biological processes to remove organic pollutants via biological degradation using methods, such as suspended biomass, fixed biomass or suspended biomass in aquatic systems. Finally, in some cases, a tertiary treatment stage is necessary to remove any residual microorganisms and toxins. The final stage is commonly carried out through chlorination, but may require advanced processes, such as ozonation, sand filtration, and membranes as well as UV.

Appendix $C$ summarizes the properties and decontamination methods for each chemical and biological agent [57-66].

\subsection{Recommendations Summary}

The following recommendations should be adopted in case of Irbid's water supply contamination:

- Water system information must be kept confidential.

- Access to facilities must be limited and controlled to all pumping stations and fuel storage areas. Moreover, access must be systematic and minimal to visitors and contractors.

- All doors must be locked and alarms must be set at pumping stations, treatment plants, vaults, and offices.

- Keys must be limited to specific individuals to prevent them from being copied or stolen. Guards must be aware at all times either at treatment plants or pumping stations.

- All manholes and access points must be secured.

- $\quad$ Lighting must be sufficient in all areas with little or no staffing presence (e.g., parking lots and treatment bays).

- $\quad$ Fences and gates must be well secured and monitored by sensors and guards.

- Cameras and sensors must be equipped in all sensitive sections of water facilities and the footage must be reviewed continuously.

- $\quad$ Reservoirs must be covered and equipped with contamination detection sensors.

- All communication protocols with relevant forces must be understood by all employees in case of any emergency. 
- A contamination early warning system must be available.

- Adequate network security must be maintained to make sure that confidential information is well secured against hacking attacks. Frequent preparedness training for all facilities workers should take place.

- Written plans and regulations should be developed to tackle any immerging situations. Existing emergency and response plans should be reviewed and updated.

- Employees must be informed and trained about updates to existing plans.

- $\quad$ Security must be made a priority; safety measures must be implemented as fast as possible.

- Computer systems, such as Supervisory Control and Data Acquisition (SCADA), must always undergo updates and improvements.

- Sampling and water decontamination methods must be applied directly after shutting down a water system after the detection of any contamination.

It is important to note that an emergency and preparedness plan has to be adopted in all regions and governorates in Jordan. We should set a telemetry system that contains sensors and all adequate methods that connect water authority with drinking water plants and station units. Through this system, any sudden change in the concentration or any change above the standards can be detected and have the ability to shut down the unit automatically when threats are detected. Adequate decontamination methods should be employed and adopted, such as UV, chlorination, filtration, air scouring, and flushing. If all recommendations are implemented, the vulnerability and, accordingly, the risk will be minimal in all water assets in Jordan. Regarding this study, the vulnerability of the Makhraba pumping station will become low, and the risk will correspondingly become low as well. In regard to the Bushra water tank, the vulnerability will reduce to moderate and the risk will correspondingly be between low and moderate, overall, mainly due to the fact that the Bushra water tank has access to a highway, which prevents the vulnerability scale from becoming low. The risk assessment after the implementation of risk mitigation on Irbid water assets is shown in Table 10 below.

Table 10. Drinking water units' risk assessment after applying risk mitigation.

\begin{tabular}{|c|c|c|c|c|c|}
\hline Drinking Water Units & Treatment Process & Consequences & Threat & Vulnerability & Risk \\
\hline Wadi Al-Arab & $\begin{array}{c}\text { Only chlorination and } \mathrm{Al}_{2}\left(\mathrm{SO}_{4}\right)_{3} \\
\left(\mathrm{KMnO}_{4}\right) \text {, polymers if turbidity exceeds } \\
60 \mathrm{NTU}\end{array}$ & 3 & 2 & 3 & 18 \\
\hline Carrier line & Chlorination at line & 3 & 2 & 3 & 18 \\
\hline Al-Nuiamah & Chlorination & 3 & 2 & 3 & 18 \\
\hline Jahfieh & Chlorination & 3 & 2 & 1 & 6 \\
\hline Asa'ara & $\begin{array}{l}\text { Chlorination, ventilation, and sand } \\
\text { filters }\end{array}$ & 3 & 2 & 1 & 6 \\
\hline Makhraba & Pumping station only & 3 & 2 & 1 & 6 \\
\hline Bushra & Water storage tank only & 3 & 2 & 3 & 18 \\
\hline Hekmah & $\begin{array}{l}\text { Chlorination, ventilation and sand } \\
\text { filters }\end{array}$ & 3 & 2 & 1 & 6 \\
\hline Kremeh & $\begin{array}{l}\text { Chlorination, sand filters, membrane } \\
\text { filter, and cartridge filter }\end{array}$ & 3 & 2 & 1 & 6 \\
\hline
\end{tabular}

\section{Conclusions}

After examining and evaluating the risks and vulnerability of water assets in the Irbid governorate, most water pumping stations, water wells, and water storage tanks were found to be at low risk. On the other hand, the Makhraba pumping station and Bushra water tank were found to be at moderate risk of contamination of possible water terrorist attacks, either by chemical and biological agents. Thus, risk mitigation methods must be 
implemented to both water assets in order to decrease the level of vulnerability and to avoid any harmful consequences on humans within the serviced areas. These methods include mitigation through policies and training, mitigation through physical protection systems (e.g., access control, lighting, fences, etc.), a water contaminant information tool (WCIT), a contamination warning system (CWS), communication with public, sampling, and choosing the appropriated decontamination methods. Following these methods, intentional contamination risks will be reduced to the minimum accepted values and will no longer be considered moderate or slightly high.

Finally, we would like to point out that research on water terrorism preparedness plans is not under enough focus worldwide, and has not yet been studied in Jordan; this study could help many countries to prepare for water terrorism situations.

Author Contributions: This paper was written with the contribution of all authors as follows: conceptualization, M.H., A.A., A.J. and R.A.; methodology, A.A., R.T., S.S. and A.J.; software, A.A. and A.J.; validation, A.A., A.J., R.A., M.J., S.J. and R.T.; formal analysis, A.A., M.H., A.J. and R.A.; investigation, A.A., M.H., A.J. and R.A.; resources, S.S., A.A, and A.J.; data curation, A.J., A.A., M.J. and S.J.; writing—original draft preparation, A.A., A.J.; writing—review and editing, A.A., R.A., S.J. and M.J.; supervision, A.A., A.J.; project administration, A.J. All authors have read and agreed to the published version of the manuscript.

Funding: This research received no external funding.

Institutional Review Board Statement: Not applicable.

Informed Consent Statement: Not applicable.

Data Availability Statement: Not applicable.

Acknowledgments: The authors would like to acknowledge the German Jordanian University, An Najah National University and Université de Haute-Alsace, 68100 Mulhouse, France, and Sultan Qaboos University, Oman, for facilitating this research.

Conflicts of Interest: The authors declare no conflict of interest.

Appendix A. Water conflicts in the Middle East region (1984-2017)

\begin{tabular}{|c|c|c|c|c|}
\hline Year & Parties Involved & Basis of Conflict & Description & Reference \\
\hline 1948 & Arabs, Israelis & Military Tool & $\begin{array}{l}\text { Arab forces cut off water supplies to West } \\
\text { Jerusalem. }\end{array}$ & {$[7,8]$} \\
\hline 1951 & Israel, Jordan, Syria & $\begin{array}{l}\text { Political tool, Military } \\
\text { tool, development } \\
\text { dispute }\end{array}$ & $\begin{array}{l}\text { Jordan decided to irrigate the Jordan Valley by } \\
\text { using the water from the Yarmouk River; Israel } \\
\text { responded by draining the Huleh swamps } \\
\text { between Syria and Israel. }\end{array}$ & {$[8,9]$} \\
\hline 1965-1966 & Israel, Syria & $\begin{array}{l}\text { Military tool, political } \\
\text { tool, control of water } \\
\text { resources, development } \\
\text { dispute }\end{array}$ & $\begin{array}{l}\text { Arab countries planned to divert the Jordan River } \\
\text { headwaters at Hasbani and Banias to tackle the } \\
\text { Israeli National Water Carrier, but Syria stopped } \\
\text { construction in July } 1966 .\end{array}$ & {$[7,8]$} \\
\hline 1967 & Israel, Jordan & Military target and tool & $\begin{array}{l}\text { Israel completely destroyed the Arab diversion } \\
\text { network on the Jordan River headwaters. }\end{array}$ & {$[7,8,10,11]$} \\
\hline 1969 & Israel, Jordan & Military target and tool & $\begin{array}{l}\text { Israel destroyed the east Ghor canal after } \\
\text { suspecting that Jordan was diverting the river of } \\
\text { Yarmouk extensively. An agreement was made in } \\
1970 \text { between Jordan and Israel, and was led by } \\
\text { the US. }\end{array}$ & [9] \\
\hline 1974 & Iraq, Syria & $\begin{array}{l}\text { Military target, military } \\
\text { tool, political tool, } \\
\text { development dispute }\end{array}$ & $\begin{array}{l}\text { Iraq claimed that the al-Thawra dam in Syria was } \\
\text { reducing the flow of the Euphrates river; thus, } \\
\text { they gathered troops along the borders and } \\
\text { threatened to bomb the dam. }\end{array}$ & [12] \\
\hline
\end{tabular}




\begin{tabular}{|c|c|c|c|c|}
\hline Year & Parties Involved & Basis of Conflict & Description & Reference \\
\hline 1981 & Iran, Iraq & Military target and tool & $\begin{array}{l}\text { Iran bombed a hydroelectric facility in Kurdistan, } \\
\text { which led to blacking out large areas of Iraq. }\end{array}$ & {$[10]$} \\
\hline 1980-1988 & Iran, Iraq & Military tool & Iran flooded Iraqi defenses by diverting water. & [13] \\
\hline 1982 & Israel, Lebanon, Syria & Military tool & $\begin{array}{l}\text { Israel cut off the water supply of Beirut during } \\
\text { the siege. }\end{array}$ & [8] \\
\hline 1990 & Iraq, Syria, Turkey & $\begin{array}{l}\text { Development dispute, } \\
\text { military tool, political } \\
\text { tool }\end{array}$ & $\begin{array}{l}\text { As part of the Grand Anatolia Project, the Ataturk } \\
\text { Dam interrupted the flow of the Euphrates for } \\
\text { around a month. Moreover, in the 1990s, Turkey } \\
\text { threatened to cut off the water flow to Syria in } \\
\text { response to Syrian support for Kurdish rebels in } \\
\text { the south of Turkey. }\end{array}$ & {$[7,10]$} \\
\hline 1991 & Iraq, Kuwait, US & Military target & $\begin{array}{l}\text { Baghdad's water systems were targeted by the } \\
\text { allied coalition. }\end{array}$ & [10] \\
\hline 1991 & Iraq, Kuwait, US & Military target & $\begin{array}{l}\text { During the retreat of Iraqi's troops from Kuwait, } \\
\text { they destroyed a large portion of the desalination } \\
\text { capacity. }\end{array}$ & [10] \\
\hline 2003 & Iraq & Terrorism & $\begin{array}{l}\text { Terrorists bombed the main water pipeline in } \\
\text { Baghdad. }\end{array}$ & [14] \\
\hline 2014 & Iraq-ISIS & Tool of war & $\begin{array}{l}\text { ISIS troops managed to siege the Haditha dam on } \\
\text { the Euphrates River for months. }\end{array}$ & [15] \\
\hline 2014 & Iraq-ISIS & Control water resources & $\begin{array}{l}\text { After the capturing of Mosul and Tikrit, ISIS cut } \\
\text { off the water supply to all surrounding areas. }\end{array}$ & [16] \\
\hline 2017 & $\begin{array}{l}\text { Syrian } \\
\text { government-Free } \\
\text { Syrian Army }\end{array}$ & Tool of war & $\begin{array}{l}\text { The water pumping station in Ain al-Fijeh near } \\
\text { the capital city Damascus was damaged during } \\
\text { the battle in Wadi Barada area. The rebels } \\
\text { poisoned the water supply source by dumping } \\
\text { large amounts of diesel into the spring. }\end{array}$ & [17] \\
\hline
\end{tabular}

\section{Appendix B. Water Sector Assets in Irbid}

- Bushra water tank: the gate of the tank is not well sealed.

- Zabda water reservoir: Well secured

- Wadi Al-Arab's Wells:

* Wadi Al-Arab well \#9

- Well secured with a fence, but the gate is not closed with a tight seal.

- Concrete casting has to be repaired.

- $\quad$ There is no tube to measure the surface of the static water.

- $\quad$ Presence of sheep grazing activities next to the first protection area.

* Wadi Al-Arab well \#14

- $\quad$ The gate is well-sealed.

- $\quad$ The concrete needs to be repaired and the well site needs some cleaning.

* Wadi Al-Arab well \#13

- Well secured with a fence and surveillance.

* Wadi Al-Arab well\#16

- Well is under construction.

* Wadi al-Arab well \#11

- The gate is not closed with a tight seal.

- $\quad$ Electrical cables are not well protected.

* Wadi Al-Arab well \#5

- $\quad$ Not well secured with a fence, and the concrete casting needs to be repaired. 


\section{* Wadi Al-Arab Water Treatment plant}

- $\quad$ It is located in the southwest of Irbid governorate.

- $\quad$ Its main tributaries are Wadi Al-Arab wells \# (1-15) and Dahleh wells.

- $\quad$ The aim of the Wadi Al-Arab treatment plant:

- $\quad$ Raw water is pumped from the supply sources, where the raw water mixture is collected in the wall structure. Water is pumped into ventilation towers to reduce high levels of sulfur and iron.

- $\quad$ Water is pumped into the coagulation ponds where the chemical coagulation material $(\mathrm{KMnO} 4), \mathrm{Al}_{2}(\mathrm{SO} 4)_{3}$, and polymers, are added only in cases where turbidity exceeds 60 NTU.

- $\quad$ After processing, the treated water is pumped to the lifting station (1) (PS1). The new lifting station (1) was constructed with a storage capacity of $3000 \mathrm{~m}^{3}$, with the aim of storing water exceeding the PS1 storage capacity when the quantity exceeds $2000 \mathrm{~m}^{3}$.

- $\quad$ The treated water is pumped to the PS2 (pumped pumping station) and then pumped to the PS3 (Deir Al-Sana) pump station.

- The treated water is pumped into a $100 \mathrm{~m}^{3}$ concrete aggregate tank, which in turn supplies a pumping station.

- $\quad$ A tank of butter is supplied from the treated water from the Za'tari pumping station through the Umm Lulu pumping station.

To improve the quality of well water, which has high concentrations of iron, sulfur, and turbidity, and is treated by ventilation,

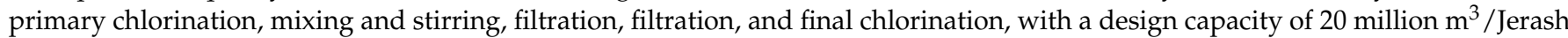
and Ajloun with treated water.

\section{* Al-Nuaimah pumping station 1}

The Nuaimah pumping station is located in the southeast of Irbid governorate, $17 \mathrm{~km}$ away from the governorate center. Raw water comes from Al-Nuaimah's well \#1 with a pumping flow of $\left(24 \mathrm{~m}^{3} / \mathrm{h}\right)$. Water is first collected in a steel tank with a $50 \mathrm{~m}^{3}$ volume, and then treated with chlorine in a chlorination unit. Finally, the chlorinated water is pumped to the serviced areas of Nuaimah and Katem.

\section{Jahfieh pumping station}

Raw water comes from two wells: Jahfieh 1 and Jahfieh 2, with a pumping flow $59\left(\mathrm{~m}^{3} / \mathrm{h}\right)$ and $100\left(\mathrm{~m}^{3} / \mathrm{h}\right)$, respectively. Water is first collected in a cement tank with a volume of $100 \mathrm{~m}^{3}$, and then treated with chlorine in a chlorination unit. Finally, the chlorinated water is pumped to the serviced areas Jahfieh, southern shrine, Deir Youssef, and Kefriuba.

\section{* Makhraba Pumping Station}

It is only a pumping station; no treatment or disinfection occurs. Wadi Al-Arab pumping station provides the station with a flow of $2400 \mathrm{~m}^{3} / \mathrm{h}$. The chlorinated water is stored in a cement tank with a capacity of $200 \mathrm{~m}^{3}$ and is distributed to serve the Makhraba area and Deir-Alsa'anah.

\section{* Asa'ara Pumping Station}

Raw water is provided from Asa'ara's well; water is pumped to the ventilation tower to remove high levels of sulfur and ferrous concentration and is passed through sand filters to decrease the level of turbidity. Finally, the treated water is collected in two metal tanks and is injected with chlorine for disinfection, to be distributed to feed the Asa'ara area and Foa'ara pumping station

\section{* Hekma Pumping Station}

Raw water is provided from the Hekma well; water is pumped to the ventilation tower to remove high levels of sulfur and ferrous concentration and is passed through sand filters to decrease the level of turbidity. Finally, the treated water is collected in a metal tank and is directly injected with chlorine for disinfection, to be distributed only once a week from the Saal area.

\section{* Kremeh Pumping station (different quality of raw water)}

Raw water comes from two wells; Kremeh well 4, Kremeh well 5, having the same rate of pumping flow of $60 \mathrm{~m}^{3} / \mathrm{h}$ to treatment units. It passes through three sand filters and then through the cartridge filters and membrane filters to remove impurities and turbidity. Chlorine is injected before water reaches the $150 \mathrm{~m}^{3}$ cement tank. Then, treated water is pumped into a $650 \mathrm{~m}^{3}$ cemented tank. Raw water is pumped from a well (1), a well (3) to a $650 \mathrm{~m}^{3}$ reservoir, and is directly injected with chlorine. The chlorinated water is pumped from the reservoir to feed the network of the town of Al-Kareemah, Abu Siddo, Saffra, Al-Qarn, Abu Abel, and Wadi Al-Rayyan.

\section{* Carrier Line /Irbid Governorate}

Raw water is pumped from the Sulaykhat Well (3), Sulaykhat well (6) and al-Sulaykhat well no. (8) through the conveyor line, which feeds the network of Abu Sidou and Al-Qarn. Water is chlorinated directly through the carrier line. 


\section{Appendix C. Pathogens and Bio-Toxins along with the Most Effective Decontamination Method(s) for Each Contaminant}

Table A1. Examples of biological pathogens that can pose a threat to drinking water systems and their properties.

\begin{tabular}{|c|c|c|c|c|c|c|c|c|}
\hline Disease & Agent & $\begin{array}{l}\text { Persistence in } \\
\text { Water }\end{array}$ & $\begin{array}{l}\text { NOAEL Daily } \\
\text { Water } \\
\text { Consumption } \\
\text { 5L/day }\end{array}$ & $\begin{array}{l}\text { NOAEL Daily } \\
\text { Water } \\
\text { Consumption } \\
\text { 15L/day }\end{array}$ & $\begin{array}{c}\text { Direct } \\
\text { Human- } \\
\text { Human } \\
\text { Transmission }\end{array}$ & $\begin{array}{l}\text { Conventional } \\
\text { Chlorination }\end{array}$ & $\begin{array}{l}\text { Incubation } \\
\text { Period }\end{array}$ & $\begin{array}{l}\text { Inactivation } \\
\text { Techniques }\end{array}$ \\
\hline Anthrax & $\begin{array}{l}\text { Bacillus } \\
\text { anthracis }\end{array}$ & $\begin{array}{l}2-18 \text { years in } \\
\text { water }\end{array}$ & 171 spores/L & 57 spores $/ \mathrm{L}$ & No & $\begin{array}{l}\text { Inactivation of } \\
\text { vegetative } \\
\text { form. Spore } \\
\text { form is } \\
\text { resistant }\end{array}$ & $12 \mathrm{~h}-19$ days & $\begin{array}{ll}- & >95^{\circ} \mathrm{C} \\
- & \text { Filtration }< \\
& 1 \mu \mathrm{m}\end{array}$ \\
\hline Plague & Yersinia pestis & $\begin{array}{l}16 \text { days in } \\
\text { water }\end{array}$ & 2 organisms/L & $\begin{array}{c}<1 \\
\text { organisms/L }\end{array}$ & Yes & $\begin{array}{l}\text { Inactivated by } \\
\text { chlorination }\end{array}$ & $2-5$ days & $\begin{array}{ll}- & 55-72{ }^{\circ} \mathrm{C} \\
- & \text { Sunlight } \\
- & 1 \% \text { Sodium } \\
& \text { hypochlorite }\end{array}$ \\
\hline Tularemia & $\begin{array}{c}\text { Francisella } \\
\text { tularensis }\end{array}$ & $\begin{array}{l}\text { Several } \\
\text { months in } \\
\text { water }\end{array}$ & $\begin{array}{c}3 \times 106 \\
\text { spores } / \mathrm{L}\end{array}$ & $\begin{array}{c}1 \times 106 \\
\text { spores/L }\end{array}$ & No & $\begin{array}{l}\text { Inactivated by } \\
\text { chlorination }\end{array}$ & 1-14 days & $\begin{array}{ll}- & \text { Filtration }< \\
& 0.22 \mu \mathrm{m} \\
- & \mathrm{UV} \text { radiation } \\
\text { dose } 3.4 \mathrm{~mW} \\
\mathrm{~s} / \mathrm{cm}^{2} \text { at } \\
253.7 \mathrm{~nm} \\
\end{array}$ \\
\hline \multirow[b]{2}{*}{$\begin{array}{l}\text { Food } \\
\text { safety } \\
\text { threats }\end{array}$} & $\begin{array}{l}\text { Salmonella } \\
\text { spp. }\end{array}$ & $\begin{array}{l}8 \text { days in } \\
\text { water }\end{array}$ & $\begin{array}{c}100 \\
\text { organisms/L }\end{array}$ & $\begin{array}{c}300 \\
\text { organisms/L }\end{array}$ & Yes & $\begin{array}{l}\text { Inactivated by } \\
\text { chlorination }\end{array}$ & $12-72 \mathrm{~h}$ & $\begin{array}{ll}\text { - } & \text { UV radiation } \\
\text { dose } 15.2 \\
\mathrm{~mW} \mathrm{~s} / \mathrm{cm}^{2} \\
\text { at } 253.7 \mathrm{~nm} \\
\end{array}$ \\
\hline & Shigella & $\begin{array}{l}2-3 \text { days in } \\
\text { water }\end{array}$ & $\begin{array}{c}100 \\
\text { organisms/L }\end{array}$ & $\begin{array}{c}300 \\
\text { organisms/L }\end{array}$ & Yes & $\begin{array}{l}\text { Inactivated by } \\
\text { chlorination }\end{array}$ & $48 \mathrm{~h}$ & $\begin{array}{ll}\text { - } & \text { FAC residual } \\
\text { of } 0.05 \mathrm{mg} / \mathrm{L} \\
\text { at }\left(20-29^{\circ} \mathrm{C}\right) \\
\text { UV radiation } \\
\text { dose } 3.4 \mathrm{~mW} \\
\mathrm{~s} / \mathrm{cm}^{2} \text { at } \\
253.7 \mathrm{~nm} \\
\end{array}$ \\
\hline Glanders & $\begin{array}{c}\text { Burkholderia } \\
\text { mallei }\end{array}$ & $\begin{array}{l}30 \text { days in } \\
\text { water }\end{array}$ & $\begin{array}{c}9 \times 104 \\
\text { spores } / \mathrm{L}\end{array}$ & $\begin{array}{c}3 \times 104 \\
\text { spores } / \mathrm{L}\end{array}$ & Yes & Unknown & 2-6 weeks & $\begin{array}{ll}1 \% \text { Sodium } \\
\text { hypochlorite }\end{array}$ \\
\hline Psittacosis & $\begin{array}{l}\text { Chlamydia } \\
\text { psittaci }\end{array}$ & $\begin{array}{l}18-24 \mathrm{~h} \text { in } \\
\text { seawater }\end{array}$ & unknown & unknown & Rare & $\begin{array}{l}\text { Inactivated by } \\
\text { chlorination } \\
(3 \mathrm{~g} / \mathrm{L} \\
\text { chloramine- } \mathrm{T})\end{array}$ & 5-14 days & $\begin{array}{ll}-\quad & 1 \% \text { Sodium } \\
& \text { hypochlorite } \\
\text { - } & \text { Sensitive to } \\
\text { heat and } \\
\text { most } \\
\text { disinfectants }\end{array}$ \\
\hline$Q$ fever & $\begin{array}{l}\text { Coxiella } \\
\text { burnetii }\end{array}$ & $\begin{array}{l}160 \text { days in } \\
\text { water }\end{array}$ & $\begin{array}{c}<1 \\
\text { organisms/L }\end{array}$ & $\begin{array}{c}<1 \\
\text { organisms/L }\end{array}$ & Rare & Unknown & 2-3 weeks & $>65^{\circ} \mathrm{C}$ \\
\hline $\begin{array}{l}\text { Typhus } \\
\text { fever }\end{array}$ & $\begin{array}{l}\text { Rickettsia } \\
\text { prowazekii }\end{array}$ & Unknown & $\begin{array}{c}<1 \\
\text { organisms } / L\end{array}$ & $\begin{array}{c}<1 \\
\text { organisms/L }\end{array}$ & Yes & Unknown & 5-18 days & $\begin{array}{ll}\text { - } & \text { Sensitive to } \\
\text { heat } \\
\text { - } \quad 1 \% \text { Sodium } \\
\text { hypochlorite }\end{array}$ \\
\hline \multirow{2}{*}{$\begin{array}{l}\text { Water } \\
\text { safety } \\
\text { threats }\end{array}$} & Vibrio cholerae & $\begin{array}{l}6 \text { days in } \\
\text { water }\end{array}$ & $\begin{array}{c}10 \\
\text { organisms/L }\end{array}$ & $\begin{array}{c}30 \\
\text { organisms/L }\end{array}$ & Unlikely & $\begin{array}{l}\text { Inactivated by } \\
\text { chlorination }\end{array}$ & $1-5$ days & $\begin{array}{l}1 \% \text { Sodium } \\
\text { hypochlorite }\end{array}$ \\
\hline & $\begin{array}{l}\text { Cryptosporidium } \\
\text { parvum }\end{array}$ & $\begin{array}{l}\text { Several weeks } \\
\text { in water }\end{array}$ & \multicolumn{2}{|c|}{0.01 oocyst/L } & Yes & $\begin{array}{l}\text { Cannot be } \\
\text { inactivated by } \\
\text { chlorination }\end{array}$ & 1-14 days & $\begin{array}{l}\text { Ozone } \\
\text { inactivation } \\
\text { at } 20^{\circ} \mathrm{C}\end{array}$ \\
\hline
\end{tabular}

Table A2. Examples of bio-toxins that can pose a threat to drinking water systems and their properties.

\begin{tabular}{|c|c|c|c|c|c|}
\hline Bio-Toxin & Source Agent & $\begin{array}{l}\text { NOAEL Daily } \\
\text { Water } \\
\text { Consumption } \\
\text { 2L/day }\end{array}$ & Stability in Water & $\begin{array}{l}\text { Conventional } \\
\text { Chlorination }\end{array}$ & Detoxification Techniques \\
\hline Aflatoxin & $\begin{array}{c}\text { Aspergillus flavus } \\
\text { A. parasiticus }\end{array}$ & $0.5-15 \mu \mathrm{g} / \mathrm{L}$ & Probably stable & Can be removed & $\begin{array}{ll}- & \text { Ozone }(13-95 \%) * \\
- & \text { Ammoniation }(79-90 \%) \text { * } \\
\text { - } & \text { Redox-active enzymes } \\
& (<96 \%)^{*}\end{array}$ \\
\hline Anatoxin A & Cyanobacteria & Unknown & Inactivated in days & Not effective & $\begin{array}{l}\text { - } \\
\text { - } \\
\text { - } \\
\text { - } \\
\quad \text { Advane } \\
\text { Activated carbon } \\
\text { adsorption }\end{array}$ \\
\hline
\end{tabular}


Table A2. Cont.

\begin{tabular}{|c|c|c|c|c|c|}
\hline Bio-Toxin & Source Agent & $\begin{array}{l}\text { NOAEL Daily } \\
\text { Water } \\
\text { Consumption } \\
\text { 2L/day }\end{array}$ & Stability in Water & $\begin{array}{l}\text { Conventional } \\
\text { Chlorination }\end{array}$ & Detoxification Techniques \\
\hline $\begin{array}{l}\text { Botulinum } \\
\text { toxins }\end{array}$ & C. Botulinum & $0.0004 \mu \mathrm{g} / \mathrm{L}$ & Stable & $6 \mathrm{ppm}, 20 \mathrm{~min}$ & $\begin{array}{ll}-\quad & >80^{\circ} \mathrm{C} \\
-\quad & \text { Reverse osmosis }\end{array}$ \\
\hline Microcystins & Cyanobacteria & $1 \mu \mathrm{g} / \mathrm{L}$ & Probably stable & Effective if $\mathrm{pH}<8$ & $\begin{array}{ll}\text { - } & \text { Potassium permanganate } \\
\text { - } & \text { Ozone } \\
\text { - } & \text { Advanced oxidation } \\
& \text { adsorption }\end{array}$ \\
\hline Ricin & Castor beans & $15 \mu \mathrm{g} / \mathrm{L}$ & Stable & Resistant at 10 ppm & $\begin{array}{ll}- & >80{ }^{\circ} \mathrm{C} \\
- & \text { Reverse osmosis } \\
- & \text { FAC treatment }\end{array}$ \\
\hline Saxitoxin & Cyanobacteria & $0.4 \mu \mathrm{g} / \mathrm{L}$ & Stable & $\begin{array}{l}\text { Prior filtration is rec- } \\
\text { ommendedresistant at } \\
10 \text { ppm }\end{array}$ & $\begin{array}{l}\text { Activated carbon } \\
\text { adsorption }\end{array}$ \\
\hline $\begin{array}{l}\text { Staphylococcal } \\
\text { enterotoxins }\end{array}$ & Staphylococcus aureus & $0.1 \mu \mathrm{g} / \mathrm{L}$ & Probably stable & Unknown & $\begin{array}{l}\text { Limited information } \\
\text { available }\end{array}$ \\
\hline T-2 mycotoxin & $\begin{array}{l}\text { Fusarium, } \\
\text { Myrothecium, and } \\
\text { Stachybotrys }\end{array}$ & $65 \mu \mathrm{g} / \mathrm{L}$ & Stable & Resistant & $\begin{array}{ll}\text { - } & 1 \% \text { alkaline sodium } \\
\text { hypochlorite solution } \\
\text { - } & \text { Ozone } \\
\text { - } & \text { Calcium hydroxide }\end{array}$ \\
\hline Tetrodotoxin & $\begin{array}{l}\text { Fish and marine } \\
\text { animals }\end{array}$ & $1 \mu \mathrm{g} / \mathrm{L}$ & Stable & Inactivated at $50 \mathrm{ppm}$ & $\begin{array}{l}\text { Limited information } \\
\text { available }\end{array}$ \\
\hline
\end{tabular}

* Values were tested for feed and food samples.

\section{References}

1. Westall, F.; Brack, A. The importance of water for life. Space Sci. Rev. 2018, 214, 50. [CrossRef]

2. Vuorinen, H.S.; Juuti, P.S.; Katko, T.S. History of water and health from ancient civilizations to modern times. Water Sci. Technol. Water Supply 2007, 7, 49-57. [CrossRef]

3. Curnin, S.; Brooks, B. Making waves: How do we prepare for the next drinking water disaster? Water Res. 2020, $185,116277$. [CrossRef] [PubMed]

4. Beck, S.; Uppu, P.; Kopansky, R.; Golembeski, J.E.; Black, S.; Burlingame, G.A. Incident Response: Practice Makes Perfect. J. Am. Water Works Assoc. 2019, 111, 24-31. [CrossRef]

5. Frith, J. Arsenic-the "poison of kings" and the "saviour of syphilis". J. Mil. Veterans Health 2013, 21, 11-17.

6. Butts, K.H. The strategic importance of water. US Army War College Q. Parameters 1997, $27,1$.

7. Wolf, A.T. Hydropolitics along the Jordan River: Scarce Water and Its Impact on the Arab-Israeli Conflict; United Nations University Press: Tokyo, Japan, 1995; Volume 99.

8. Wolf, A.T. International water conflict resolution: Lessons from comparative analysis. Int. J. Water Resour. Dev. 1997, 13, 333-366. [CrossRef]

9. Samson, P.R.; Charrier, B. International Freshwater Conflict: Issues and Prevention Strategies; Green Cross International: Geneva, Switzerland, 1997; p. 6.

10. Gleick, P.H. Water and conflict: Fresh water resources and international security. Int. Secur. 1993, 18, 79-112. [CrossRef]

11. Swain, A.; Wallensteen, P. Comprehensive Assessment of the Freshwater Resources of the World. In International Fresh Water Resources: Conflict or Cooperation; Stockholm Environment Institute (SEI): Stockholm, Sweden, 1997.

12. Gleick, P.H. Water, war \& peace in the Middle East. Environ. Sci. Policy Sustain. Dev. 1994, 36, 6-42.

13. Plant, G. Water as a Weapon in War. In Proceedings of the Water and War: Symposium on Water in Armed Conflicts, Montreux, Switzerland, 21-23 November 1994; International Committee of the Red Cross: Geneva, Switzerland.

14. Tierney, J.; Worth, R.F. Attacks in Iraq may be signals of new tactics. The New York Times, 18 August $2003 ; 1$.

15. Schwartzstein, P. Amid Terror Attacks, Iraq Faces Water Crisis. National Geographic. 2014. Available online: http://news. nationalgeographic.com/news/2014/11/141104-iraq-water-crisis-turkey-iran-isis (accessed on 11 September 2021).

16. ISIS Cuts Off Water, Electricity, Destroys Churches. 2014. Available online: Aina.org (accessed on 11 September 2021).

17. ReliefWeb. No Water in Damascus Hitting Hard—Syrian Arab Republic. 2017. Available online: https://reliefweb.int/report/ syrian-arab-republic/no-water-damascus-hitting-hard (accessed on 11 September 2021).

18. Federal Bureau of Investigation. Terrorism 2002/2005 I Federal Bureau of Investigation. Available online: https://www.fbi.gov / stats-services/publications/terrorism-2002-2005 (accessed on 11 September 2021). 
19. Mueller, R., III. War on Terrorism. In FBI; 2003. Available online: https:/ /archives.fbi.gov/archives/news/testimony/war-onterrorism (accessed on 11 September 2021).

20. Matalas, N.C. Vulnerability of water systems to acts of terrorism and acts of nature. In Risk-Based Decisionmaking in Water Resources X; ASCE: Reston, VA, USA, 2003; pp. 82-90.

21. Gleick, P.H. Water and terrorism. Water Policy 2006, 8, 481-503. [CrossRef]

22. Amrose, S.E.; Cherukumilli, K.; Wright, N.C. Chemical contamination of drinking water in resource-constrained settings: Global prevalence and piloted mitigation strategies. Annu. Rev. Environ. Resour. 2020, 45, 195-226. [CrossRef]

23. Water Resources Center Archives (Calif.) and California Water Resources Center. In Bulletins and Reports of California State Water Agencies: An Annotated Listing (No. 15); Water Resources Center, University of California: Los Angeles, CA, USA, 1963.

24. World Health Organization. Available online: https://apps.who.int/iris/bitstream/handle/10665/44584/9789241548151_eng. pdf;jsessionid=3D35164C5B2C9D3D20A06A2B142B1CF5? sequence=1 (accessed on 11 September 2021).

25. US EPA. U.S. Environmental Protection Agency I US EPA. Available online: https://www.epa.gov/wqc (accessed on 11 September 2021).

26. Carvalho, F.P. Pesticides, environment, and food safety. Food Energy Secur. 2017, 6, 48-60. [CrossRef]

27. Mandal, B.K.; Suzuki, K.T. Arsenic round the world: A review. Talanta 2002, 58, 201-235. [CrossRef]

28. Wattana, M.; Bey, T. Mustard gas or sulfur mustard: An old chemical agent as a new terrorist threat. Prehosp. Disaster Med. 2009, 24, 19-29. [CrossRef]

29. Jack, C.; Dacre, W.D.B.; Dacre, J.C.; Burrows, W.D. Recommended Field Drinking Water Criteria for Chemical Agent Sulfur Mustard; NTIS: Springfield, VA, USA, 1988.

30. Dunn, M.A.; Sidell, F.R. Progress in medical defense against nerve agents. JAMA 1989, 262, 649-652. [CrossRef] [PubMed]

31. Somani, S.M.; Solana, R.P.; Dube, S.N. Toxicodynamics of nerve agents. In Chemical Warfare Agents: Toxicity at Low levels; Academic Press, Inc.: New York, NY, USA, 1992; pp. 67-123.

32. Weir, A.G.A.; Makin, S.; Breeze, J. Nerve agents: Emergency preparedness. BMJ Mil. Health 2020, 166, 42-46. [CrossRef] [PubMed]

33. Valcik, J.E. Biological Warfare Agents as Potable Water Threats. Medical Issues. Information Paper No. IP-31-017; US Army Center for Health Promotion and Preventative Medicine: Aberdeen, MD, USA, 1998.

34. Emergency CDC. CDC | Bioterrorism Agents/Diseases | Emergency Preparedness \& Response. 2018. Available online: https:/ / emergency.cdc.gov/agent/agentlist-category.asp (accessed on 11 September 2021).

35. Salameh, E.; Shteiwi, M.; Al Raggad, M. Water Resources of Jordan: Political, Social and Economic Implications of Scarce Water Resources; Springer International Publishing: Cham, Switzerland, 2018.

36. Komendantova, N.; Marashdeh, L.; Ekenberg, L.; Danielson, M.; Dettner, F.; Hilpert, S.; Wingenbach, C.; Hassouneh, K.; Al-Salaymeh, A. Water-Energy Nexus: Addressing Stakeholder Preferences in Jordan. Sustainability 2020, 12, 6168. [CrossRef]

37. Abu Qdais, H.; Abdulla, F.; Kurbatova, A. Wastewater reuse in Jordan and its potential as an adaptation measure to climate change. J. Environ. Eng. Sci. 2019, 14, 203-211. [CrossRef]

38. Water Sector Facts \& Figures. Jordan Ministry of Water and Irrigation. 2015. Available online: https://www.mwi.gov.jo/ebv4.0 /root_storage/ar/eb_list_page/\%D9\%82\%D8\%B7\%D8\%A7\%D8\%B9_\%D8\%A7\%D9\%84\%D9\%85\%D9\%8A\%D8\%A7\%D9\%8 7_\%D8\%AD \%D9\%82\%D8\%A7\%D8\%A6\%D9\%82_\%D9\%88\%D8\%A7\%D8\%B1\%D9\%82\%D8\%A7\%D9\%85_-2015.pdf (accessed on 11 September 2021).

39. Influx of Syrian Refugees in Jordan-Effects on the Water Sector; Helmholtz Centre for Environmental Research-UFZ: Amman, Leipzig, 2021.

40. USAID. U.S. Agency for International Development. 2020. Available online: https://www.usaid.gov/jordan/water-andwastewater-infrastructure (accessed on 11 September 2021).

41. Department of Homeland Security US. Critical Infrastructure and Key Resources Sector-Specific Plan as input to the National Infrastructure Protection Plan. Available online: https://www.dhs.gov/xlibrary/assets/Water_SSP_5_21_07.pdf (accessed on 11 September 2021).

42. Brashear, J.P.; Jones, J.W. Risk analysis and management for critical asset protection (RAMCAP plus). In Wiley Handbook of Science and Technology for Homeland Security; ASME Innovative Technologies Institute: Washington, DC, USA, 2010; Volume 2, pp. 1-15.

43. Herrick, C.; Blaha, F.J. Information disclosure and security information protection at water utilities. J.-Am. Water Works Assoc. 2007, 99, 40-42. [CrossRef]

44. US EPA. Water Contaminant Information Tool (WCIT) I US EPA. Available online: https://www.epa.gov/waterdata/watercontaminant-information-tool-wcit (accessed on 11 September 2021).

45. Huff, J.E.; Bigger, J.M. Cyanide Removal from Refinery Wastewater Using Powdered Activated Carbon; Environmental Protection Agency, Office of Research and Development, Robert S. Kerr Environmental Research Laboratory: Ada, OK, USA, 1980 ; Volume 1.

46. Adams, M.D. Removal of cyanide from solution using activated carbon. Miner. Eng. 1994, 7, 1165-1177. [CrossRef]

47. Cyanide in Drinking Water. 2007. Available online: https://www.who.int/water_sanitation_health/dwq/cyanide.pdf (accessed on 11 September 2021).

48. Welter, G.; Lechevallier, M.; Spangler, S. Guidance for Decontamination of Water System Infrastructure; Water Research Foundation: Denver, CO, USA; Alexandria, VA, USA, 2009. Available online: https://www.waterrf.org/research/projects/guidancedecontamination-water-system-infrastructure (accessed on 11 September 2021). 
49. Kobya, M.; Soltani, R.D.C.; Omwene, P.I.; Khataee, A. A review on decontamination of arsenic-contained water by electrocoagulation: Reactor configurations and operating cost along with removal mechanisms. Environ. Technol. Innov. 2020, 17, 100519. [CrossRef]

50. Ghosh, S.; Debsarkar, A.; Dutta, A. Technology alternatives for decontamination of arsenic-rich groundwater-A critical review. Environ. Technol. Innov. 2019, 13, 277-303. [CrossRef]

51. Munro, N.B.; Talmage, S.S.; Griffin, G.D.; Waters, L.C.; Watson, A.P.; King, J.F.; Hauschild, V. The sources, fate, and toxicity of chemical warfare agent degradation products. Environ. Health Perspect. 1999, 107, 933-974. [CrossRef] [PubMed]

52. Weetman, C.; Notman, S.; Arnold, P.L. Destruction of chemical warfare agent simulants by air and moisture stable metal NHC complexes. Dalton Trans. 2018, 47, 2568-2574. [CrossRef] [PubMed]

53. Jabbour, C.R.; Parker, L.A.; Hutter, E.M.; Weckhuysen, B.M. Chemical targets to deactivate biological and chemical toxins using surfaces and fabrics. Nat. Rev. Chem. 2021, 5, 370-387. [CrossRef] [PubMed]

54. Talmage, S.S.; Watson, A.P.; Hauschild, V.; Munro, N.B.; King, J. Chemical warfare agent degradation and decontamination. Curr. Org. Chem. 2007, 11, 285-298. [CrossRef]

55. Moon, S.Y.; Proussaloglou, E.; Peterson, G.W.; DeCoste, J.B.; Hall, M.G.; Howarth, A.J.; Hupp, J.T.; Farha, O.K. Detoxification of chemical warfare agents using a Zr6-based metal-organic framework/polymer mixture. Chem.-Eur. J. 2016, 22, 14864-14868. [CrossRef]

56. Bartolomeu, M.; Neves, M.G.P.M.S.; Faustino, M.A.F.; Almeida, A. Wastewater chemical contaminants: Remediation by advanced oxidation processes. Photochem. Photobiol. Sci. 2018, 17, 1573-1598. [CrossRef]

57. Spencer, R.C. Bacillus anthracis. Bristol. J. Clin. Pathol. 2003, 56, 182-187. [CrossRef]

58. Raber, E.; Burklund, A. Decontamination options for Bacillus anthracis-contaminated drinking water determined from spore surrogate studies. Appl. Environ. Microbiol. 2010, 76, 6631-6638. [CrossRef] [PubMed]

59. Bitton, G. Microbiology of Drinking Water Production and Distribution; Wiley: Hoboken, NJ, USA, 2014.

60. Burrows, W.D.; Renner, S.E. Biological warfare agents as threats to potable water. Environ. Health Perspect. 1999, 107, 975-984. [CrossRef] [PubMed]

61. CDC. Salmonella in the Caribbean. 2013. Available online: https://ehp.niehs.nih.gov/doi/pdf/10.1289/ehp.99107975 (accessed on 11 September 2021).

62. Van Zandt, K.E.; Greer, M.T.; Gelhaus, H.C. Glanders: An overview of infection in humans. Orphanet J. Rare Dis. $2013,8,131$. [CrossRef] [PubMed]

63. Islam, M.; Doyle, M.P.; Phatak, S.C.; Millner, P.; Jiang, X. Persistence of enterohemorrhagic Escherichia coli O157: H7 in soil and on leaf lettuce and parsley grown in fields treated with contaminated manure composts or irrigation water. J. Food Protect. 2004, 67, 1365-1370. [CrossRef] [PubMed]

64. Guerrant, R.L.; Walker, D.H.; Weller, P.F. Tropical Infectious Diseases: Principles, Pathogens and Practice E-Book; Elsevier Health Sciences: Amsterdam, The Netherlands, 2011.

65. Medema, G.; Teunis, P.; Blokker, M.; Deere, D.; Davison, A.; Charles, P.; Loret, J.F. WHO Guidelines for Drinking Water Quality: Cryptosporidium; WHO: New York, NY, USA, 2006; Volume 138.

66. Haas, C.N.; Rose, J.B. Developing an action level for Cryptosporidium. J.-Am. Water Works Assoc. 1995, 87, 81-84. [CrossRef] 